\title{
The Song of Songs: Its Basic Teaching and Place in the OT Canon
}

\author{
Philip Igbo \\ https://dx.doi.org/10.4314/jrhr.v13i1.2
}

\section{Abstract}

The Song of Songs is a love poem (or a collection of poems), full of sensuous symbols. The central theme of the book is love; it celebrates human love in all its physical dimensions. Its language is love, a language which seems daring and sometimes even shocking, considering its seeming erotic feature. The author provides a teaching on the place of love and marriage in God's plan of creation. It focuses on fidelity and mutuality in love between the sexes. The author offers a perspective of love not found elsewhere in the biblical writings. The climax of his teaching on love is contained in Sg 8:6-7. Here the poet emphasizes the power and energy of love. He compares the consuming power of love to "a raging flame" (rišpê 'ěš) which no water can quench. He specifies the value of love: love is so priceless that no material wealth can match it.

Keywords: Love, Fire, Lover, Beloved, Solomon, yāh.

\section{Introduction}

The Song of Songs is unique among the OT books in spirit, content and form. The book deals with a theme quite different from the usual themes of the Wisdom Literature. The book is a love poem; it contains thirty poems or songs celebrating the mutual love of man and woman, written in the form of a dialogue between two lovers. The two lovers are largely anonymous - a woman, who is the primary speaker in the poems and who is referred to twice only as "the Shulammite" (Sg 6:13), and a man who is understood to be Solomon (Sg 1:1; 3:7) but never addressed as such. Throughout, the lovers 
speak to each other using vibrant imagery that richly evokes all the senses and powerfully conveys their love. The book is distinctive in the striking way it uses imageries to portrays the power of genuine love. It compares the power of love to an unquenchable fire: it is a consuming force, it is relentless. The power of love is also compared to the power of death. Just as death is an irresistible and relentless force, so also love does not give up. In a more forceful dimension, the author compares the power and energy of genuine love to "a raging flame. This underlines the overwhelming power of genuine love. Love is so priceless that all the wealth of this world cannot buy love. The Song of Songs took quite some time before it gained admission into the Jewish canon. Two factors are largely responsible for the late acceptance of the book into the Jewish canon. The first factor is its troubling erotic subject matter; the second is the fact that the book lacks a religious theme; it makes no direct reference to God; the divine name occurs only once and then only as an epithet ( $\mathrm{Sg} \mathrm{8:6).Its}$ inclusion in the OT canon is based on the assumption of a Solomonic authorship of the text. This article exposes the power of love in the Song of Songs, using an exegetico-theological method.

\section{Problem of Authorship}

The title, "Song of Songs," is a literal translation of the Hebrew title, šîrhaššîrîm. The title, "Song of Songs" (šîrhaššîrîm), like "the holy of holies", "the vanity of vanities" or "the king of kings" is a Hebraism, i.e., it is a Hebrew way of expressing the superlative. Thus, the expression, "Song of Songs", as Waterman (1948) has said, means "the most excellent song" or "the most beautiful of songs."In the opinion of the editor, the Song was the greatest or the most sublime of Solomon's prosodic compositions.

The superscription (1:1) seems to lay claim to a Solomonic authorship: "The Song of Songs, which is Solomon's" (šîrhaššîrîm 'ăšerlišlōmōh,Sg 1:1). The occurrence of the title (Sg 1:1) with 
Solomon's name led to the attribution of the Book to him. However, the traditional claim to Solomonic authorship finds little support in the Book itself. Nowhere in the book is Solomon designated as one of the speakers; the speakers are anonymous individuals (a woman and a man) and a collective entity - the "Daughters of Jerusalem (Murphy, 1990). References to Solomon are in the third person (Sg 1:5; 3:7, 9, $11 ; 8: 11-12)$.

The prepositional phrase lišlomōh (literally: "to Solomon") is ambiguous. The Hebrew preposition le is used in a number of ways. It may be interpreted here to mean "of" or "for." The relative clause, " "ăšerlišlōmōh," could mean "which is to" or "for Solomon." The phrase, according to Murphy, suggests that the book "belongs to" Solomon as its author or "is written by" or "is dedicated to" Solomon (Garrett and House, 2004; Igbo, 2020). It may also imply that the book was written "in the spirit of" Solomon or concerns him as its subject.The attribution of the work to Solomon is probably influenced by $14: 32$ where Solomon is said to have composed three thousand proverbs and a thousand and five songs. Solomon is considered the traditional patron and founder of the Wisdom Movement. Today, no serious scholar believes that Solomon was the author of the book. The almost universal consensus of modern scholars is that the book is anonymous (Dentan, 1971).

\section{The Unity of the Songs}

The question of authorship, which has already been discussed above, is complicated by the issue of the unity of the Song. Is the book a collection of disparate poems, authored by several composers over a course of several centuries, or are the individual units of poetry the work of a single author? There are two main views as regards the unity of the book. The first view holds that the entire composition is the work of a single author. The second position is that the Song of Songs is an anthology. 


\section{a. Single Authorship}

Quite a few scholars hold that the Song of Songs is the work of a single author. Indeed, the title of the book suggests that the book is a connected whole, and is the work of one author, even though the author is not explicitly identified. Some factors indicate the hand of one author or editor at work in this book: (1) There are three main characters in the book: the beloved maiden, the lover, and the daughters of Jerusalem. These characters are seen throughout the book. This fact provides a helpful indication in favour of unity of authorship. (2) The second factor which leaves the impression that a single author or editor was responsible for the book is the abundant repetition of words and phrases, and the repeated refrains and themes throughout the book. The unity of theme and style suggests one hand at work throughout the book. Authors, like Davidson (2003) and Murphy (1979), agree that the book is a unified song, not an anthology. Murphy (1979) points to recurring refrains, themes, words, phrases, and elements of dialogical structure. The similar expressions and figures of speech are used throughout the book; this points to the hand of one author or editor. For example, the use of expressions like "your love is better than wine" (Sg 1:2; 4:10), "fragrant oil perfumes" $(1: 3,12 ; 3: 6 ; 4: 10)$, "the beloved's cheeks" (1:10; 5:13), "her eyes like doves" $(1: 15 ; 4: 1)$, "her teeth like sheep" $(4: 2 ; 6: 6)$, "her charge to the daughters of Jerusalem" $(2: 7 ; 3: 5 ; 8: 4)$, "the lover like a gazelle" $(2: 9,17 ; 8: 14)$ points to a single work, not an anthology (Tanner, 1997).

\section{b. The Anthology View}

While the one authorship view has several supports, some scholars deny any essential unity in the book and understand the Song of Songs as an anthology, i.e., it is a collection of love poems which praise the love between two lovers." Authors like Fischer (2011), 
Rendtorff (1991) and Harrelson (1990)argue that the book is a collection of love songs, written by multiple authors at different times in Israel's history, probably beginning as far back as the days of Solomon or shortly thereafter. While these scholars hold that the Song celebrates human love and sexuality, they maintain that it has no unifying thematic organization since the book is a collection of poems rather than a single composition. However, the view that the Song is a mere collection of disconnected love poems faces a problem. The abundant evidence of repeated refrains, and common literary devices throughout the book works against the view that multiple authorship (Tanner, 1997).

\section{Date of Composition}

One of the issues that scholars find problematic is not only the question of authorship, as we have already seen, but also the question of the date of the book. Most of the books of the Ketûbîmare late in origin, but it does not follow that the Song of Songs is a late writing. Meek and Kerr (1956) consider the Song of Songs as an early writing; it is placed in the Ketûb $\underline{i} m$ because of its peculiar features. Murphy suggests three factors that can help us figure out the date of the Song of Songs: (1)If, as the Superscription suggests, Solomon authored the work, then the work must be dated to the tenth century B.C. However, the Solomonic authorship of the Songs is not sustained in the book itself. This would make the tenth century date untenable. (2)The reference to "Tirzah" in 6:4 seems to suggest some geographical data. Tirzah was the capital of the northern kingdom before Omni moved the capital to Samaria in the first half of the ninth century B.C. (cf. 1 Kgs 14:17; 16:23-24). The connection of the book with Tirzah, according to Murphy, can be sustained if we limit our consideration to particular verses or poems (Sg 6:4). (3) The third factor that help determine the date of the book is the language of the Song. The 
presence of loan words like the Greek 'appiryôn ( $\mathrm{Sg}$ 3:9) and the Persian $\operatorname{pardēs}(\operatorname{Sg} 4: 13)$ suggests a post-exilic date.

Another determinant factor in the consideration of date is the literary genre of the Song of Songs. The language of the book is distinctive within the Wisdom Literature. Garrett and House (2004) hold that "the language of the Song resembles Mishnaic words in many ways." These authors, on the basis of the linguistic arguments, date the book to the Persian period.

\section{Distinctive Character of the Book}

Among the Wisdom Writings, the Song of Songs is distinctive in character, content and structure. The text is a lyric poetry of exquisite beauty, full of sensuous symbols; it is a love poem (or a collection of poems).While the book is classed among the Wisdom Books, it deals with a matter quite different from the usual themes and topics of the other Wisdom Books (Ceresko, 2005). It is marked by frequent repetitions, refrains and antiphonal responses. It is manifestly folk poetry, not belles-lettres. It is full of elaborate imagery and metaphors (Meek; Kerr; and Kerr, Jr., 1956). The unifying theme of the book is love, the highest and fullest expression of the human heart. It celebrates human love in all its physical dimensions. Its language is love, a language which seems daring and sometimes even shocking, considering its seeming erotic character.

The Song of Songs is the only book of the Hebrew Bible which has its content put into the mouth of speakers; it is a monologue with particularly no dialogue. The speakers are not identified by name (Meek; Kerr; and Kerr, Jr., 1956); they are a young man (lover or bridegroom), a young woman (beloved or bride), and the daughters of Jerusalem. The content of the Book is entirely secular in feature; this, according to Otto Kaiser (1975), explains why there was much argument over the permissibility of reading it in a service and its inclusion into the Jewish canon. 
The Song of Songs is the only Book in the OT Canon that lacks a religious or national theme. It is also one of only two books among the books of the Hebrew Bible without direct reference to God (the other book is the Book of Esther). However, while the Book of Esther too makes no direct mention of God, its national emphasis is unmistakable. This national emphasis is lacking in the Song of Songs (Gordis, 1974). In the Song of Songs, none of the customary designations for the God of Israel, such as $y h w h$, 'él, 'ĕlōhim, etc., is present. However, there is apparently an enigmatic reference to Yahweh in in 8:6. The poet compares love to a "raging fire" (šalhe betyāh, Sg 8:6). Its flashes are flashes of fire, a raging flame.

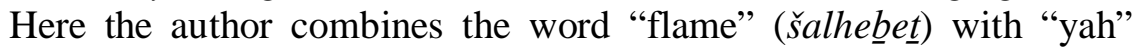
(yāh) representing the name of the Deity. Ceresco (2005) writes that "the phrase, "a raging fire", is a superlative produced by combining the word for "flame" in Hebrew with a form of the divine name, "Yahweh" ("Yah")."

\section{Place of the Song of Songs in the OT Canon}

The basic question is: How did the Song of Songs come to be accepted into the OT? When one reads the Song of Songs critically, one notices that there is no shred of ethical consciousness or social concern in the book, no reference to God, no religious theme or insight, no serious statement on faith or ethical ideas (Fuerst, 1975). Many are of the view that the book does not meet the standards of what a biblical book ought to be (Fuerst, 1975), and thus consider its presence in the Bible as an embarrassment. The absence of specifically religious themes, combined with the erotic lyrics in the book, made its acceptance into the Jewish canon difficult (Dentan, 1971).

There was a considerable dispute between the Schools of Shammai and Hillel near the beginning of the Christian era regarding the canonicity of the Song of Songs. The School of Shammai opposed 
the inclusion of the book in the Jewish Canon, but the School of Hillel supported its inclusion. At the end, the School of Hillel prevailed; eventually the book came to be accepted by all (Meek; Kerr; and Kerr, Jr., 1956). By the beginning of the $2^{\text {nd }}$ century, probably on the basis of the alleged Solomonic authorship, the book was allowed into the canon by the rabbinical Council of Jamnia ca. A.D. 90, when Judaism was being reorganized after the fall of Jerusalem (A.D. 70 [Dentan, 1971]).

Two main factors contributed to the inclusion of the Song of Songs into the Jewish Canon. The first was the occurrence of Solomon's name in the text $(1: 1)$, which led to the attribution of the whole text to him (Gordis, 1974). The association with Solomon provided an anchor for the Song within the OT Wisdom Literature and resulted in its recognition as possessing divine inspiration (Griffiths, 2005).The second factor, according to Gordis (1974), "was the allegorical interpretation of the book, according to which the love of God and Israel is described under the guise of a lover and his beloved." The combination of these two factors overcame all doubts about the sacred character of the book, and its canonicity was reaffirmed at the Council of Jamnia in A. D. 90.

In the Jewish Bible, the Song of Songs was placed in the third division, the Ketûubimor Writings (Greek: Hagiographa), which are a miscellaneous collection. It is one of the five Megilloth or the festival rolls. The Song is read annually at the Feast of the Passover, as Ruth is read at Pentecost; Lamentations on the 9th of $A b$; Ecclesiastes at the Feast of Tabernacles; and Esther at the Feast of Purim. The connection of the Song of Songs with the Passover, however, is not accidental. The Jewish Targum interpreted the Song as a picture of the history of the Hebrew nation beginning with the Exodus, an event most naturally associated with the Feast of Passover (Exod 12 [Tanner, 1997).The Song of Songs was read on the eighth day of that festival. 


\section{Hermeneutical Approaches to the Song of Songs}

The Song of Solomon has a long history of interpretation and has been read in many ways. Only few books of the Old Testament have received a plethora of interpretations as the Song of Songs. Most prominent among these interpretational approaches to the interpretation of the Song of Songs are the allegorical, literal, mythological and the literal-didactic approaches.

\section{a. Allegorical Approach}

Early Judaism interpreted the Song of Songs allegorically. Jewish interpreters, like Rabbi Aqiba (d. A.D. 137), held that the book is referring to the love between Yahweh and Israel (Kaiser, 1975; Fuerst, 1975). The prophets had constantly spoken of the marriage relationship between God and his people (cf. Hos 2:4; Ezek 16:8). Yahweh is often portrayed as the Husband or Bridegroom and Israel as His 'wife' or 'bride'. The prophet Hosea was the first prophet to portray Yahweh's covenant relationship with Israel as a kind of Marriage, one in which Israel (the bride) was unfaithful (Hos 2 [Igbo, 2020]). This same image of marriage relationship is also found in Jer 2:2; 3:20; Isa 54:4-5; 62:4-5; and Ezek 16:20. When the Christian Church accepted the Hebrew Scriptures as its Old Testament, it transferred the parable from the old Israel to the new Israel, and interpreted the Song of Songs to be an allegory which has as many as three layers of reference: the relationship between God and his people; the relationship between Christ and the Church; and the relationship between Christ and the individual Christian (Treat, 1996; Tanner, 1997).Despite the popularity of the allegorical method, its weakness is the lack of objectivity as well as the lack of consensus of meaning (Tanner, 1997). 


\section{b. Literal Approach}

The second hermeneutical approach to the Song of Songs is the literal interpretation. The allegorical theory has been generally rejected by modern scholars. In the early church, Theodore of Mopsuestia (ca. 350-428) took a stand for a literal understanding of the Song of Songs, suggesting that it should be read in its plain sense as an erotic song.

The literal interpretation, taking the Song of Songs at its face value, regards it as a love poem (or poems) celebrating in poetic fashion the bliss of romantic and sexual love between a man and a woman. According to this view, the author of the Song of Songs appraises the dignity and nobility of the human love. This intimate bond between man and woman was blessed by the Creator himself who made them male and female and implanted deep in their nature the mutual attraction that is meant to culminate in marriage. Apparently, the songs were composed to celebrate marriage or marital love (Webster, 1997).Even with the clarity of the literal approach, the popularity of the allegorical approach was so strong. This approach, however, was rejected as heresy by the Second Council of Constantinople in A.D. 553. Consequently, the literal view was virtually ignored for centuries (Tanner, 1997).

\section{c. Mythological Approach}

The Mythological approach to the interpretation of the Song of Songs is opposed to the position of the literal view. Unlike the literal view, the mythological view holds that the book does not really speak of human love at all; rather, it is concerned with the celebration of the sacred marriage of a goddess in the person of a priestess with the king. Authors who hold this view, argue that the Song originated from the Canaanite mythology where the sexual union of the goddess and her once-lost lover were seen as restoring fertility and well-being to the land. Some views hold that the songs are a reflection of the 
hierosgamus, a sacred marriage, in which sexual union of two gods (according to the Babylonian tradition Ishtar and Tammuz) was enacted cultically by a priestly couple (Rendtorff, 1991).The most difficult problem with this view, as Tanner (1997) has pointed out, is the doubt that heathen cultic songs would be admitted into the Jewish Canon, especially one of a generally immoral character.

\section{d. The Literal-Didactic Approach}

Several scholars have taken a position that while the Song should be taken literally with its expressions of romantic and sexual bliss in marriage, at the same time the Song seems to communicate a lesson on marital love that goes even deeper. Hence, the Song is didactic as well as literal. While the Song does celebrate the dignity and purity of human love, it is also didactic and moral in its purpose.

In this world of sin, where lust and passion are on every hand, where fierce temptations to promiscuity assail men and women of the modern age and try to turn them aside from the God-given standard of marriage, the book reminds us how pure and noble true love is. Not only does it speak of the purity of human love; but, by its very inclusion in the Canon, it reminds us of a love that is purer than our own (Tanner, 1997).

\section{Basic Themes of the Book}

The central theme of the book is the power of love. This theme is repeated throughout the eight chapters of the book with endless variations. Other themes include: presence and absence, seeking and finding, desire and mutual possession, etc.

\section{a. The Power of Love}

The main theme of the Song of Songs is human love in its intimate dimension. Two main characters are particularly outstanding in the 
book: the beloved maiden and her lover. The book opens with beloved's cry of desire ( $\operatorname{Sg} 1: 2-4)$ :

Let him kiss me with the kisses of his mouth! For your love is better than wine, your anointing oils are fragrant, your name is perfume poured out; therefore, the maidens love you. Draw me after you, let us make haste. The king has brought me into his chambers. We will exult and rejoice in you; we will extol your love more than wine; rightly do they love you.

Here the bride speaks, perhaps in her imagination, to her lover and desires to be united with him in marriage. In her imagination, she begs her shepherd lover to tell her where he has gone: "Tell me, you whom my soul loves, where you pasture your flock, where you make it lie down at noon..." (1:7-8).

Sg 1:9-2:7 consists of a colloquy of lovers. The speeches here alternate in a formal way, but there is no real conversation. In vvs 911 , the lover praises his beloved's beauty. The description is full of imagery. He compares her beauty to "a mare among Pharaoh's chariots, the comeliness of her cheek with "ornaments" and her neck "with strings of jewels." In vvs 12-14, the girl in return praises her lover. She compares him to "a cluster of henna blossoms in the

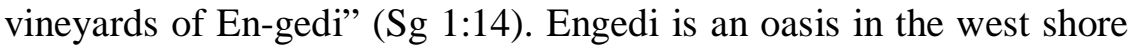
of the Dead Sea. In Sg 2:3, she compares his strength and elegance to a blossoming apple tree and likens him to "a gazelle or a young stag (Sg 2:9). In 2:10-14, the bride speaks of her lover coming to her, bounding with joy, calling to her through the windows, asking her to come into the lovely countryside. In 2:16-17, she responds to his plea and expresses her desire to spend the night with him among the fields and hills.

Chapters 4-7 describe the beauty which the lover and the beloved see in each other. In 4:1-7, the lover praises his beloved's beauty. The passage is full of similes that would seem grotesque to the modern reader. He compares her eyes to "doves" behind her veil, her hair to 
"a flock of goats moving down the slopes of Gilead" (probably a reference to her long-flowing black hair, Sg 4:1), her teeth to the freshly washed ewes ( $\operatorname{Sg} 4: 2$ ), probably a reference to its whiteness. The bride in turn praises the height and the strength of the bridegroom, comparing him to the stately and nourishing palm tree (Sg 7:6-9).

Sg 4:8-5:1 again consists of a colloquy of love. In 4:9-11, without shame or apology, the two lovers describe their experience of love and elaborate on the joys and pleasures of the sexual expression of that love. The bridegroom praises the kisses and other charms of his beloved (4:9-11) and refers to her as "my sister, my bride" (4:9, 10,12 and 5:1). The words "my bride" or "my sister, my bride" occurs five times in Sg 4:8, 9-12; 5:1. In 4:9-11, the Bridegroom describes his experience of love:

You have ravished my heart, my sister, my bride, you have ravished my heart with a glance of your eyes, with one jewel of your necklace. How sweet is your love, my sister, my bride! how much better is your love than wine, and the fragrance of your oils than any spice! Your lips distill nectar, my bride; honey and milk are under your tongue; the scent of your garments is like the scent of Lebanon ( $\mathrm{Sg}$ 4:9-11).

By means of similes, the groom speaks of the purity of his bride ("my sister, my bride"). He compares her to "a garden locked, a fountain sealed" - inaccessible virgin ( $\mathrm{Sg} 4: 12)$. This is probably a reference to her moral integrity and virginal purity. In 4:15, he compares her to "a garden fountain, a well of living water, and flowing streams from Lebanon." The comparison of a wife to a "fountain" is also found in Prov 5:15-18. In 4:16, the girl begs the winds to entice her lover into his garden. In 5:1, he accepts her invitation. In 5:1e, as if addressing guests at a wedding feast, he said: "Eat, friends, drink, and be drunk with love." This would suggest that the poem has a marriage setting. 
The Book provides a teaching on the place of love and marriage in God's plan of creation. The author offers a perspective of love not found elsewhere in the biblical writings. Other biblical books deal with marriage and relations between the sexes from a social and religious point of view; the Song of Songs, by contrast, emphasizes the personal aspects of marriage. It focuses on fidelity and mutuality in love between the sexes (Ceresko, 2005).

The bride also exults in her love for the bridegroom and vividly describes his excellent qualities:

My beloved is all radiant and ruddy, distinguished among ten thousand. His head is the finest gold; his locks are wavy, black as a raven. His eyes are like doves beside springs of water, bathed in milk, fitly set. His cheeks are like beds of spices, yielding fragrance. His lips are lilies, distilling liquid myrrh. His arms are rounded gold, set with jewels. His body is ivory work, encrusted with sapphires. His legs are alabaster columns, set upon bases of gold. His appearance is like Lebanon, choice as the cedars. His speech is most sweet, and he is altogether desirable. This is my beloved and this is my friend, $\mathrm{O}$ daughters of Jerusalem ( $\mathrm{Sg}$ 5:10-16).

\section{The Power of Love (Sg 8:6-7)}

Sg 8:6-7 may be described as a climactic point in the Song of Songs. The tone of this passage is didactic and wisdom-like. Sg 8:6 is arguably the most profound of the entire book. This is the only place in the whole of the book where attempt is made to probe the meaning of genuine love. In verse $6 \mathrm{a}$, the girl makes an impassioned plea which reveals the intensity of her desire: "Set me as a seal upon your

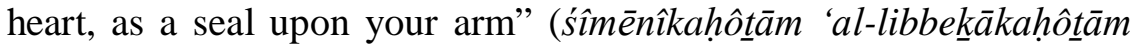
'al-zerố 'ek $\bar{a}$ ). Seals were symbols of ownership and of personal identification; they were near the heart (cf. Gen 39:18) or worn by the arm. The woman asks that the man marks her on his heart and arm. 
Here the heart (le $\underline{b})$ refers to inner being, one's personality; the arm (zerôa") refers to his action. Taken together, "heart" and "arm" signify the whole person (Longman, 2001). What the woman desires here is that she may have a place in the man's heart.The author employs three striking metaphors to describe the dimension of the depth and lasting endurance of genuine love (vv.6b-7).

In v.6b, the woman gives a motive for her request to the man. It is a very strong statement of desire for him, although he phrases it in a form of a general statement principle: Love is as strong as death $(k \hat{\imath}-$ 'azzāhkammāwet 'ahăb $\underline{a} h$ ). In this statement, she compares the power of love to the power of death (8:6b). Death is an irresistible and inevitable force. Nothing can stop death. So also is the power of love. Roland Murphy (1990) writes that "the emphasis is not upon the threat which death (môt) undoubtedly constitutes for humans, but upon its sheer force and relentlessness." Just as death has an overwhelming power, love has a consuming force."Love will not give up, but will pursue the loved one just as persistently as the great and fearful power of 'death.'" Just as one cannot fight off death when it approaches, so also one cannot fight off love. The woman expresses her belief that her desire to hold on to the man and to have him hold on to her will surpass even the power of death(Longman, 2001).

The author takes the characterization of genuine human love to a more forceful dimension in v.6c. Here he describes the power and energy of love. He compares the consuming power of love to "a raging flame" ( $r i \check{s} p \hat{e}$ ' $\bar{e} s$ ). The poet concludes with the strongest of all superlatives. He compares the force oflove to "flames of Yah[weh]" (̌́alhebetyāh), literally a "mighty flame."The Hebrew word šalhebetyāh("a raging flame") is a superlative produced by combining the Hebrew word for "flame" ( $\check{s}$ alhe $\underline{b} o \underline{t}$ ) with a form of the divine name "Yahweh" ("yāh") (2005). The sense of this comparison is ambiguous. The strange Hebrew word, šalhebetyāh (8:6), ends with $y \bar{a} h$, a shortened form of the name of God. What is debatable is 
whether the word $-y \bar{a} h$ suffixed on lehäbah should be regarded as a divine name (thus šalhebetyāhmay be rendered as "flames of Yah") or whether the word should be taken as the use of the divine name in the sense of a superlative. Tournay (1988)is of the view that, even if šalhebetya $\bar{a}$ is taken to have a superlative use in this passage, it should be translated as "a divine flash of lightning." By projecting this translation, Tournay seems to underline the force of love. Authors like Bergant (2001) and Longman (2001) argue that the word šalhebetya $h$ is not an actual reference to the deity, rather it is used here to express intensity or the superlative. This statement underlines the overwhelming mystery of love (Black, 2021),and represents the intensity of passion.

In v.7, the woman continues her strong statement of love's intensity. Love is like a fire that cannot be put out. For the author, the flame of true love is like a raging flame; it burns so intensely that even an abundance of water, i.e., "great waters" (mayimrabbîm), cannot quench it.

\section{The Priceless Value of Love}

The author specifies the value of love, particularly of wedded love. For him, the foundation of all happiness in the married state is the mutual love between husband and wife. The poet affirms that love isso pricelessthat no material wealth can match it. He pits love against another powerful force, money (the wealth of his house). Money will bring many things, but it cannot buy love. In 8:7b, the author stresses the futility of any attempt by anyone to buy love with material resources. The material property (hôn) referred to here is not the bride-price (môhar) that a man brings to marriage. What the author intends here is not the customary exchange, but what one is willing to give (nātan) in exchange for love (Bergant, 2001). Thus, for a womanto 'sell' herself for money to a man whom she does not love, or for a man to tie himself for life to a woman whom he dislikes or 
despises, for the sake of wealth, is nothing but mutual misery. The poet, thus, urges his readers not to attempt to trade love for anything, even great wealth: "If one offered for love all the wealth of his house, it would be utterly scorned."

\section{b. Presence and Absence; Separation and Search}

One of the themes that runs through the book is "presence and absence," "separation and search." The beloved is portrayed as being alone and her lover appears to be at a distance. She expressed her longing for his kiss and likened that to a tasty wine (Sg 1:2). The lover is absent, yet present in the heart of his beloved.

The theme, "Presence and Absence" introduces a subtheme, "Separation and Search" (Sg 3:1-4; 5:2-8; 6:1; 4:8). The double question, 'where' ('êkāh) and 'where' (Sg 1:7), introduces the search motif into the prologue: Tell me, you whom my soul loves, where you pasture your flock, where you make it lie down at noon; for why should I be like one who is veiled beside the flocks of your companions? (Sg 1:7).

The theme of search appears again in Sg 5:2-8. The lover has come and gone. Presence has given way to absence, and the search motif resumes. The beloved wanders through the streets seeking for her lover.

Chapter 3 portrays the anguish of searching for a love that is gone: 'I sought him and did not find him' ( $\operatorname{Sg~3:1).~She~went~}$ searching through the streets of the city for her lover, but she did not find him, she enquired, but no one could give her any information about her lover. Discouraged, she gave up the search and returned home and then to her surprise her lover suddenly appeared. This suggests that her lover had never left her; he only seemed to have departed. This iswhat happens when one takes love, especially the love of God for granted: it seems to disappear. And after an apparent absence, love is rediscovered and experienced at a much deeper level. 


\section{Seeking and Finding}

Another important theme, which is still linked to the theme of love, is the theme of seeking and finding. As 3:1-5 indicates the girl dreams of her lover. In her dream, she wanders through the narrow streets of the town in search of her lover. When she finds him, she brings him back to her home.

$\mathrm{Sg}$ 5:2-6:3 is usually captioned the "nocturnal search for the lover." Verses 2-8 have a dreamlike quality and may be intended as a description of a dream (cf. 3:1-5). The lover knocks at the bride's door after she has fallen asleep (vv.2-4). When she rises to admit him, he is gone (v.6). Being "faint with love," she goes in search of him through the dark streets.Not finding him, she pleads to the "daughters of Jerusalem" to "tell" her beloved if they find him (5:8). The girl expresses longing for her lover (8:1-4). She wishes that she could always have her lover near her, like a brother, so that she could freely express her affection. The emotion she feels, however, is not sisterly but passionately sensual $(8: 3 ;$ cf. $2: 6)$.

\section{Conclusion}

The Song of Songs is a unique book in the Bible. The central theme of the book is love; The Song was most likely a collage of wedding songs sung across the Jewish world (Kaplon, 2012). The book offers a spirituality of love and sexuality. Such a spirituality, as Ceresko (2005) has said, would give support and encourage loyalty to ideals about marriage. There is a plethora of interpretations of the Song of Songs. The allegorical interpretation views the text as referring to the love between God and his people. The allegorical method, however, has a number of weaknesses. It lacks objectivity and consensus in its view. This level of interpretive schemes is guilty of reading too much meaning into the text, rather than allowing the text to speak for itself (Tanner, 1997).The literal reading of the text considers it as addressing the topic of the romantic and sexual experience within 
God-ordained marriage. The literal-didactic view seems to be the best approach to take. This approach holds that the text stresses the elements of fidelity and devotion.

The author compares the overwhelming power of love to the power of death; its sparks are sparks of fire; its flame is an enormous flame. The comparison with death does not suggest that love is a threat to human life; the emphasis is the sheer force and relentlessness of genuine love. Just as death has an overwhelming power, love has a consuming force; it does not give up on the beloved; it endures.

Again the poet compares love with fire; its force is as intense and as fierce as the force of fire. The fire of love is like a fierce fire that cannot be quenched by any water (mayim) or nähar(river). The author takes the characterization of genuine human love to "flames of Yah[weh]" (šalhebetyāh). What is intended here is intensity or the superlative. This statement underlines the overwhelming mystery of love (Black, 2021). True love burns so intensely as "a raging fire" that nothing can quench it. Just like one cannot fight off death when it approaches, so nothing can fight off love. In this way the author underlines the priceless value of love, particularly of wedded love. The poet affirms that love is so priceless that no material wealth can match it. In $8: 7 \mathrm{~b}$, the author stresses the futility of any attempt by anyone to buy love with material resources. The material property (hôn) referred to here is not the bride-price (môhar) that a man brings to marriage (Bergant, 2001); it speaks against any attempt to trade love for material wealth: "If one offered for love all the wealth of his house, it would be utterly scorned." Thus, for a woman to sell herself for money to a man whom she does not love, or for a man to tie himself for life to a woman whom he dislikes or despises, for the sake of wealth, is nothing but mutual misery. 


\section{References}

Bergant, D. (2001). The Song of Songs. Berit Olam. Studies in the Hebrew Narrative and Poetry.

Black, F. C. (2021). Love as Strong as Death (Song 8:6-7).Retrieved online on January 11, 2021 from https://www.bibleodyssey.org.

Ceresko, A. R. (2005). Introduction to Old Testament Wisdom. A Spirituality for Liberation. Bandra, Mumbai: St Pauls.

Davidson, R. M. (2003). "The Literary Structure of the Song of Songs." Journal of the Adventist Theological Society. 14/2. Pp.44-65.

Dentan, R. C. (1971). The Song of Songs. In The Interpreter's OneVolume Commentary on the Bible. C. M. Laymon (Ed). Nashville: Abingdon.

Fischer, S. (2011). "What's turning the wheel? The theological hub of Song of Songs." Acta Theologica 1. Pp.61-62. Retrieved on January 11, 2021 from https://www.ajol.info.

Fuerst, W. J. (1975). The Books of Ruth, Esther, Ecclesiastes, The Song of Songs, Lamentations.The Cambridge Bible Commentary. Cambridge: Cambridge Uni. Press.

Garrett, D and House, P. R. (2004). Song of Songs/Lamentations. WBC 23B. B. M. Metzger, et al (Eds). Nashville: Thomas Nelson.

Gordis, R. (1974). The Song of Songs and Lamentations. New York:

Ktav Publishing House.

Griffiths, P. J. (2005). Song of Songs. Grand Rapids: Baker Academy.

Harrelson, W. (1990). Song of Songs. Lutterworth Dictionary of the bible. W. E. Mills (Ed).

Cambridge: The Lutterworth Press.

Igbo, P. (2020). Introduction to the Old Testament Books and Pseudepigrapha. Enugu: San Press.

Kaiser, O. (1975). Introduction to the Old Testament. Oxford: Western Printing Services.

Kaplon, M. P. (2012). "Contradiction in Marriage and Love in the Song of Songs, " Inquiries.

Vol 4, No. 7. Pp.1-2. Retrieved on Jan 2, 2021 from http://inquiriesjournal.com. 
Longman III, T. (2001). Song of Songs. The New International Commentary on the Old

Testament. R. K. Harrison \& R. L. Hubbard (Eds). Grand Rapids: Eerdmans.

Meek, T. J; Kerr, H. T; and Kerr, H. T. Jr. (1956). Song of Songs. The Interpreter's Bible in

Four Volumes. Vol. 5. G. A. Buttrick (Ed). New York: Abingdon.

Murphy, R. E. (1979). "The Unity of the Song of Songs," VT 29. Pp. 436-443.

Murphy, R. E. (1990). The Song of Songs. Minneapolis: Fortress Press. 1990.

Rendtorff, R. (1991). The Old Testament: An Introduction. Philadelphia: Fortress Press.

Tanner, J. P. (1997). "The History of Interpretation of the Song of Songs," Bibliotheca

Sacra 154: 613. Pp.23-46.

Treat, J. C. (1996). "Lost Keys: Text and Interpretation in Old Greek "Song of Songs" and Its

Earliest Manuscript Witnesses," Penn Libraries. Jay Curry Treat (1996), p.4.

Retrieved on January 11, 2021 from https://repository.upenn.edu.

Tournay, R. J. (1988). Word of God, Song of Love. New Jersey: Paulist Press.

Waterman, L. (1948). The Song of Songs. Wisconsin: George Banta Publishing Company.

Webster, E. C. (1997). "Pattern in the Song of Songs," in The Poetical Books. A Sheffield

Reader. D. J. A. Clines (Ed). Sheffield: Sheffield Academic Press.

Philip Igbo (CMF, PhD) is a lecturer in Spiritan International School of Theology, Attakwu, Enugu, Nigeria. 